\title{
Analysis of Service Quality and Institutional Image on Satisfaction and the Implications on Customer Loyalty (Case Study: Yadika 12 Depok Junior High School)
}

\author{
Aisya Intan Widya Satria*, Adi Nurmahdi \\ Universitas Mercu Buana, Jl. Meruya Selatan No.1, RT.4/RW.1, Meruya Sel., Kec. Kembangan, Kota Jakarta Barat, Daerah Khusus Ibukota Jakarta \\ 11650, Indonesia
}

DOI: $10.36348 /$ sjbms.2020.v05i03.001

| Received: 13.09.2019 | Accepted: 20.09.2019 | Published: 07.03.2020

*Corresponding author: Aisya Intan Widya Satria

\section{Abstract}

This study aims to analyze service quality and institutional image of customer satisfaction and implications for customer loyalty (case study: Yadika 12 Depok Junior High School). The research data uses primary and secondary data. Secondary data was obtained from various sources such as journals, books and other related publications, as well as through school administration staff and also the vice principal of the academic field. Primary data was collected using a questionnaire distributed to respondents, namely parents and students Yadika 12 Depok Junior High School. The sampling method used in this study is quota sampling with 122 respondents. The analyst method uses path analysis using SPSS version 22. The results shown that service quality and institutional image have a positive and significant effect on customer satisfaction. Furthermore, service quality does not affect customer loyalty, while institutional image through customer satisfaction has a positive and significant effect on customer loyalty. And customer satisfaction has a positive and significant effect on customer loyalty. School management effort that can be done is to improve and develop sustainably, and maintain the quality and image of a good institution.

Keywords: Service Quality, Institution Image, Customer Satisfaction, Customer Loyalty.

Copyright @ 2020: This is an open-access article distributed under the terms of the Creative Commons Attribution license which permits unrestricted use, distribution, and reproduction in any medium for non-commercial use (NonCommercial, or CC-BY-NC) provided the original author and source are credited.

\section{INTRODUCTION}

Education plays an important role which is a supporting factor in all sectors. Basically, humans need education in their lives. Education is an effort so that humans can develop their potential through learning processes and/or other ways known and recognized by the community. Institutions on track Formal education plays an important and vital role in the development of human resources in Indonesia. Based on Law No. 20 of 2003 concerning the national education system, it is explained that formal education is a structured and tiered educational path consisting of basic education, secondary education, and higher education. Formal education institutions are at the forefront of human resource development in Indonesia, where we now know that the formal education pathway is still a mainstay in educating the public, both at the elementary, middle and high levels, formal education institutions are always relied upon to make generations the successor generation of Indonesia is becoming more qualified.

One of the educational institutions included in formal education institutions is junior high school (SMP). Formal education in Indonesia is not only organized by the government, but also organized by the private sector. The existence of private institutions also helps the government in an effort to educate all Indonesian people. Private schools are generally under the auspices of a foundation or organization that has a legal entity. Yadika 12 Junior High School is a private school that is under the auspices of the Abdi Karya Foundation which is located in the Depok city area of 
the Limo sub-district and began its establishment in 2012.

As a private education institution, Yadika 12 Junior High School is faced with quality problems. Quality is one of the top priorities for Yadika 12 Junior High School in the implementation of education. From year to year, Yadika 12 Junior High School always wants to improve its quality so that the goals of establishing the school can be achieved. Quality is the focus of Yadika 12 Junior High School because as an organization, they are also faced with competition from other private schools. Based on the data of the Yadika 12 Junior High School in the last 5 years, namely from the 2014-2015 school year to 2018/2019 there were fluctuations in the number of students. This is illustrated in the graph presented in Figure-1.

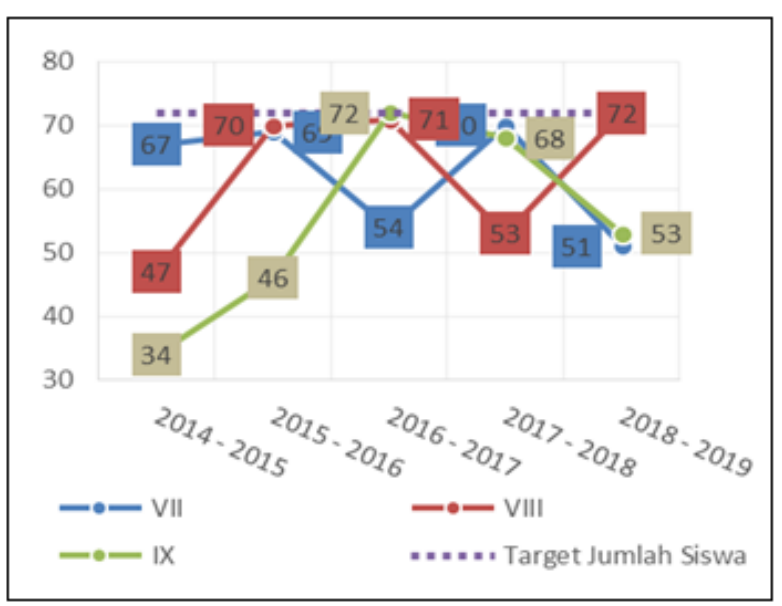

Fig-1: Data on Number of Yadika 12 Junior High School Students Academic Year 2014-2015 until 2018-2019

The number of classes in Yadika 12 Junior High School is 6 classes consisting of classes VII A and VII B, classes VIII A and VIII B, as well as classes IX A and class IX B. The capacity of students in each class is a maximum of 36 people. In each new school year, the school has a target of receiving 72 students. Based on graph 1 shows that the number of new class VII students who re-register at Yadika 12 Junior High School in the last 5 years always fluctuates and never reaches the target.

One of the things that affects customer satisfaction in the field of educational services is the image of education providers [1]. Students as service users in education hope to get satisfaction with the services provided, where satisfaction is an important parameter for a business to continue. Increasing the image and services provided by educational services will bring the impact of the spread of positive information by users of educational services to the general public through word of mouth [2, 3]. Positive information will be very helpful in increasing the market share of goods or services from an institution [4]. In Martenson [5] study, it is known that there is a strong relationship between "Corporate Image" and "satisfaction" and between "satisfaction" and "loyalty". Customer satisfaction is formed from a series of strategies carried out by the company continuously to form a good and positive feeling. This strategy is more oriented to service quality, price and image.

Good service quality will create, maintain satisfaction and make loyal customers. Based on the description of the background, this study aims to analyze the service quality and institutional image of satisfaction and its implications for customer loyalty (Case Study: Yadika 12 Depok Junior High School).

\section{THEORITICAL REVIEW \\ Service Quality}

Service quality can be defined as how far the difference between reality and customer expectations for services received [6]. According to Pratama [7], service quality is an effort to fulfill the needs and desires of customers as well as the accuracy of delivery in balancing customer expectations which include physical evidence, reliability, responsiveness, assurance and empathy, each of which has an equally important role. Service quality greatly determines customer satisfaction. Customer expectations and customer experience will bring up a standard definition of service which then becomes an assessment of a particular product or service. To achieve customer satisfaction, companies must pay attention to the quality of services offered. This is because only with the quality of service, customers can be satisfied and will correlate with the customer's intention to re-use or buy the company's products.

\section{Institution Image}

Image is the impression that someone feels about an object or item or organization as a whole which will then be stored in consumer memory [8]. Jasfar \& Kristaung [9], stated that to form a good image, the company must build a good name and reputation and strengthen its competence. Therefore building and then maintaining the image is important for a service organization if you want to get and maintain customer loyalty [10]. Positive images will benefit the organization and a bad image will harm the organization. Imagery can influence consumer decisions in purchasing products or services. According to Kotler et al., [11] images can be formed through symbols, media, atmosphere and events.

\section{Customer Satisfaction}

According to Kotler [8], satisfaction is the level of feeling after comparing the performance that he feels with his expectations. So that the level of satisfaction is a function of the difference between perceived performance and expectations. If performance is below expectations, consumers are not satisfied. If performance is in line with expectations, consumers will be satisfied. If performance exceeds 
expectations, consumers will be very happy or very satisfied. Schnaars in Tjiptono [12] suggests that the purpose of a business is to create customers who are satisfied. Superior service quality and consistency can foster customer satisfaction and will provide various benefits, including relationships between institutions and their customers to be harmonious, providing a good basis for service users.

\section{Customer Loyalty}

Customer loyalty is the customer's decision to voluntarily continue to subscribe to certain companies for a long time. Tjiptono and Chandra [13] argue that customer loyalty is a customer who is loyal to a particular brand that tends to be tied to the brand and will buy the same product again even though there are many other alternatives available. High appreciation for the company if it is able to establish customer loyalty and can refer the company to its peer partners. This means that trust and satisfaction are inherent in his heart. This needs to be maintained and sought new or innovative things so that this loyalty continues to be formed.

\section{FRAMEWORK \& HYPOTESIS}

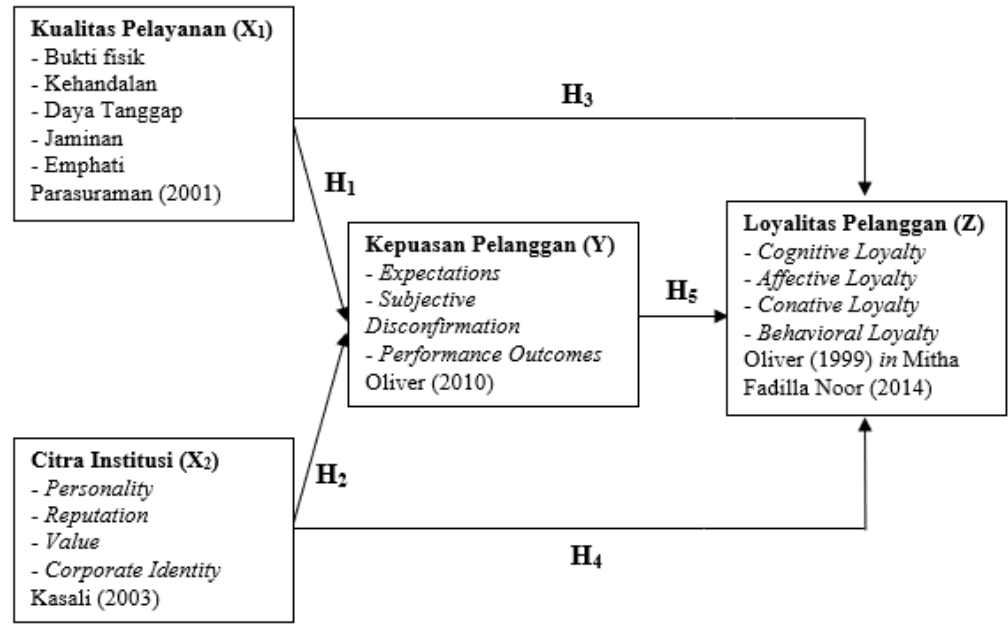

Framework

In this analysis model, there are independent variables, namely Service Quality $\left(\mathrm{X}_{1}\right)$, Institutional Image $\left(\mathrm{X}_{2}\right)$ and dependent variable (dependent variable), namely Customer Loyalty $(\mathrm{Z})$. In addition to the two types of variables above, in this study there are also intervening variables, namely Customer Satisfaction (Y). The following is the framework of the study:

\section{Hypotesis}

Based on the background of the problem, literature review and framework, the hypotheses used in this study are:

H1: Service quality has a positive effect and significant to customer satisfaction.

$\mathrm{H} 2$ : Institutional image has a positive and significant effect on customer satisfaction.

H3: Service quality has a positive and significant effect on customer loyalty.

H4: Institutional image has a positive and significant effect on customer loyalty.

H5: Customer satisfaction has a positive and significant effect on customer loyalty.

\section{RESEARCH METHODS}

The approach used in this study is a quantitative approach. Data collected are primary data and secondary data. Secondary data was obtained from various sources such as journals, books and other related publications, as well as through school administration staff and also the vice principal of the academic field. Primary data was collected using a questionnaire distributed to respondents, namely parents and students Yadika 12 Depok Junior High School. The scale of data measurement carried out is the Linkert scale data, this scale has characteristics such as those owned by nominal and ordinal scales with added other characteristics, namely in the form of a fixed interval. The sampling method used in this study is quota sampling. The analyst method uses path analysis (path analysis) using Statistical Package for Social Science (SPSS) version 22.

Determination of the number of samples using the Slovin approach, with an error rate (e) of 5\%. Based on the formula, the number of samples to be studied is 122 respondents. Tests carried out in this study include: (1) Test of research instruments, namely validity and reliability testing, (2) Classical Assumption Test which includes Normality Test, Multicollinearity and Heteroskedatisitas, (3) Hypothesis Test includes $\mathrm{T}_{\text {Test }}$ (Partial Influence), $\mathrm{F}_{\text {Test }}$ (Simultaneous Influence), Path Analysis, Determinant Coefficient Analysis $\left(\mathrm{R}_{2}\right)$ and Inter-Dimensional Correlation Test. 


\section{RESULTS}

\section{Validity and Reliability Test}

Validity test uses a confidence level of $95 \%$, where $\mathrm{df}=$ alpha, $\mathrm{n}-2, \mathrm{n}$ is the number of samples in the study that is 122 , then $\mathrm{df}=120$. That way, the value of $r_{\text {tabel }}$ is 0,1779 . So that the validity of the data can be said to be valid if the results of $r_{\text {table }}>0,1779$. While the criteria for a research instrument are said to be reliable if the reliability coefficient is $>0,6$. Based on the test, the following results are obtained:

- Service quality variable $\left(\mathrm{X}_{1}\right)$ is valid and realistic

- Institutional image variables $\left(\mathrm{X}_{2}\right)$ are valid and realistic

- Customer satisfaction variable (Y) is valid and realistic

- Customer loyalty $(\mathrm{Z})$ variable is valid and realistic

\section{Classic Assumption Test \\ Normality Test}

This study is to test the research data with normal distribution or not. If the data is normally distributed, parametric analysis including regression models can be used. To detect the normal distribution of research data is by analyzing the histogram graph and P-P plot of the regression stand. Based on research results, the histogram graph shows that the data distribution is in the center line of the bell. Whereas in the P-P Plot graph, the output data from this study is seen to spread following the normality reference line, then the regression model has been normal and is suitable to be used to predict the independent variable.

Furthermore, another normality test is performed by using the non-parametric statistical test Kolmogorov-Smirnov (KS) with the results of the normality test of service quality variables $\left(\mathrm{X}_{1}\right)$, institutional image $\left(\mathrm{X}_{2}\right)$, customer satisfaction $(\mathrm{Y})$, and customer loyalty (Z), namely significance value of 0,200 . So from that it can be concluded that the data is normally distributed, on the basis of decision making, namely:

- If the significance value (Asym Sig 2 tailed)> 0,05 means that the residual data is normally distributed.

- If the significance probability value (Asym Sig 2 tailed) $<0,05$ means that the residual data is not normally distributed.

\section{Multicollinearity Test}

Multicollinearity test is used to see the correlation between independent variables. In this test it is known that the variable service quality $\left(\mathrm{X}_{1}\right)$, institutional image $\left(\mathrm{X}_{2}\right)$, customer satisfaction $(\mathrm{Y})$, and customer loyalty $(\mathrm{Z})$ is obtained VIF value of less than 10.00 and Tolerance is more than 0.100 for both independent variables and one variable dependent, it can be concluded that the regression model does not occur or is free of multicollinearity problems, meaning that there is no relationship (correlation) between independent variables.

\section{Heterocedasticity Test}

Heterocedasticity test is useful to determine whether there is heterocedasticity. One way to find out is to use a graph of the plot between the bound and residual values. Based on research results, it can be seen that the diagrams is scattered and do not form a pattern or it can be concluded that there is no heterocedasticity in the regression model, so that a decent regression model is used to predict customer loyalty and customer satisfaction based on input independent service quality and institutional image.

\section{Hypothesis Test \\ T Test (Partial Effect Test)}

This $t_{\text {test }}$ statistic is used to find out whether there is a partial effect between service quality and institutional image on customer satisfaction and customer loyalty. To find out the truth of the hypothesis, criteria are used if $t_{\text {count }}>t_{\text {table }}$, then $\mathrm{H}_{0}$ is rejected and $\mathrm{Ha}$ is accepted, whereas if $\mathrm{t}_{\text {count }}<\mathrm{t}_{\text {table }}$ then $\mathrm{H}_{0}$ is accepted and $\mathrm{Ha}$ is rejected. This means that there is an influence between the independent variables on the dependent variable and the significance level used at $5 \%$. The ttable value in this study is determined at alpha $=5 \%: 2$ (2-sided test) with degrees of freedom (df) n-k1 or $122-3-1=118$ ( $\mathrm{n}$ is the number of samples, $\mathrm{k}$ is the number of independent variables). With 2-sided testing ( significance $=0,025$ ) the results obtained for $t$ table are 1,98027 .

\section{Hypothesis:}

- $\mathrm{H}_{0}$ : There is no influence between independent variables on the dependent variable $\left(t_{\text {count }}<\right.$ $\left.t_{\text {table }}\right)$.

- Ha: There is an influence between independent variables on the dependent variable $\left(t_{\text {count }}>\right.$ $\left.t_{\text {table }}\right)$.

From the results of the study conclusions can be drawn: H1: Service quality has a significant effect on customer satisfaction. With a tcount of $3,965>1,98027\left(\mathrm{t}_{\text {count }}>\mathrm{t}_{\text {table }}\right)$, it means that $\mathrm{H}_{0}$ is rejected and $\mathrm{Ha}$ is accepted. While the sig value of the variable service quality is $0,000<$ 0,05 .

H2: Institutional image significantly influences customer satisfaction. With a $t_{\text {count }}$ of 4,869>1,98027 ( $\mathrm{t}_{\text {count }}>\mathrm{t}_{\text {table }}$ ), it means that $\mathrm{H}_{0}$ is rejected and $\mathrm{Ha}$ is accepted. While the sig value of the institutional image variable is $0,000<0,05$.

H3: Service quality has an indirect effect on customer loyalty. With a $t_{\text {count }}$ of $0,556<$ $1,98027\left(\mathrm{t}_{\text {count }}<\mathrm{t}_{\text {table }}\right)$, means $\mathrm{H}_{0}$ is accepted. While the sig value of the service quality variable is $0,579>0,05$ 
H4: Institutional image has a significant effect on customer loyalty. With a $t_{\text {count }}$ of $5,746>1,98027\left(\mathrm{t}_{\text {count }}>\mathrm{t}_{\text {table }}\right)$, means $\mathrm{H}_{0}$ is rejected $\mathrm{Ha}$ accepted. While the sig value of the Institution Image variable is $0,000<0,05$.

H5: Customer satisfaction significantly influences customer loyalty. With a $t_{\text {count }}$ of $3,241>1,98027\left(\mathrm{t}_{\text {count }}>\mathrm{t}_{\text {table }}\right)$, it means that $\mathrm{H}_{0}$ is rejected Ha accepted. While the value of Sig. from the variable Customer Satisfaction of $0,002<0,05$.

\section{F Test (Simultaneous Effect Test)}

The simultaneous test with this F-test aims to determine the effect jointly between the independent variables on the dependent variable. The results of this F-test indicate that service quality variables $\left(\mathrm{X}_{1}\right)$ and institutional image $\left(\mathrm{X}_{2}\right)$ have a joint effect on customer satisfaction (Y) and customer loyalty (Z).

The results of this F-test can be seen in the ANOVA table contained in SPSS 22 output. From the ANOVA table 1 results obtained $F_{\text {count }}$ of 68,716 with a significance level of 0,000 , because the probability is less than 0,05 significance of $0,000<0,05$, the hypothesis has been proven and acceptable. So that it can be stated that service quality $\left(\mathrm{X}_{1}\right)$ and institutional image $\left(\mathrm{X}_{2}\right)$, have a significant effect on customer satisfaction $(\mathrm{Y})$.

Furthermore, based on ANOVA table 2 obtained $F_{\text {count }}$ of 59,946 with a significance level of 0,000 , because the probability is less than 0,05 significance of $0,000<0,05$, the hypothesis has been proven and acceptable. So that it can be stated that service quality $\left(\mathrm{X}_{1}\right)$ does not have an indirect effect on customer loyalty. Whereas for institutional image $\left(\mathrm{X}_{2}\right)$ and customer satisfaction (Y) significantly influence jointly towards customer loyalty (Z).

\section{Path Analysis}

This study uses path analysis with the help of SPPS analysis tools. To conduct path analysis, the relationship structure on the above path diagram will be divided into 2 models, namely analysis of sub-structure 1 and sub-structure 2 .

\section{Sub-Structure Path Analysis 1}

Sub-structure 1 is the one that connects the Service Quality variable $\left(\mathrm{X}_{1}\right)$, Institutional Image $\left(\mathrm{X}_{2}\right)$ and Satisfaction (Y). Following is the sub-structure 1 diagram illustrated as follows:

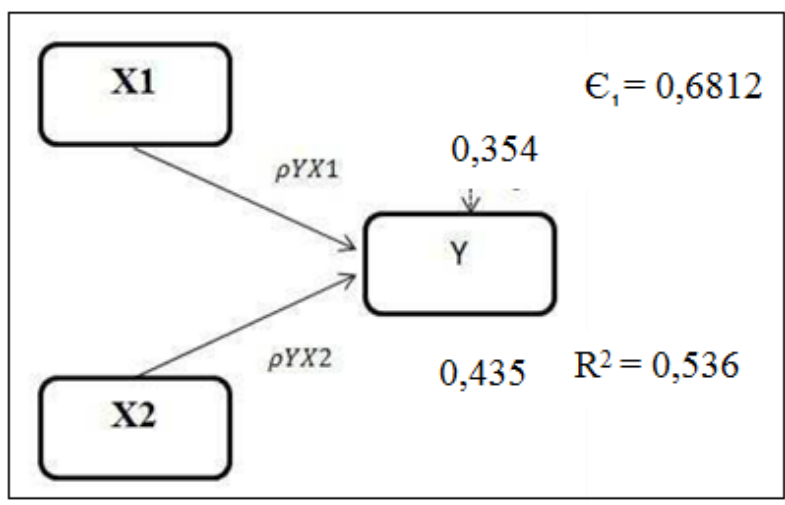

Fig-5: Sub-structure Path Chart Model 1

Thus the structural equation for sub-structure 1 can be obtained as follows:

$$
\begin{aligned}
& Y=\rho y x_{1} X_{1}+\rho y x_{2} X_{2}+\epsilon_{1} \\
& Y=0,354 X_{1}+0,435 X_{2}+0,6812
\end{aligned}
$$

Where is $R^{2}=0,536$

For the value $\epsilon_{1}$ can be searched by the formula:

$$
\mathbf{C}_{1}=\sqrt{ }(\mathbf{1}-\mathbf{0 , 5 3 6})=0,6812
$$

Based on the structural equation sub-structure 1, it can be interpreted that:

- Service quality $\left(\mathrm{X}_{1}\right)$ is $\mathrm{Sig}=0,000$ or $<0,05, \mathrm{H}_{0}$ is accepted and $\mathrm{Ha}$ is rejected. Thus it can be concluded that the service quality variable $\left(\mathrm{X}_{1}\right)$ has a significant effect on the customer satisfaction variable (Y) with a beta coefficient of 0,354 . This shows that there is a positive influence between the service quality variable $\left(\mathrm{X}_{1}\right)$ on the Customer Satisfaction variable (Y).

- Institutional image $\left(\mathrm{X}_{2}\right)$ obtained a value of Sig = 0,000 or, $<0,05$, then $\mathrm{H}_{0}$ is accepted and $\mathrm{Ha}$ is rejected. Thus it can be concluded that the variable institutional image $\left(\mathrm{X}_{2}\right)$ has a significant effect on the customer satisfaction variable $(\mathrm{Y})$ with a beta coefficient of 0,435 . This shows that there is a positive influence between institutional image variables $\left(\mathrm{X}_{2}\right)$ on the Customer Satisfaction variable $(\mathrm{Y})$.

\section{Sub-Structure Path Analysis 2}

Sub-structure 2 is the one that connects the variables of Service Quality (X1), Imagery Image $\left(\mathrm{X}_{2}\right)$, Satisfaction (Y), and Customer Loyalty (Z). The following is a sub-structure 2 diagram illustrated as follows: 


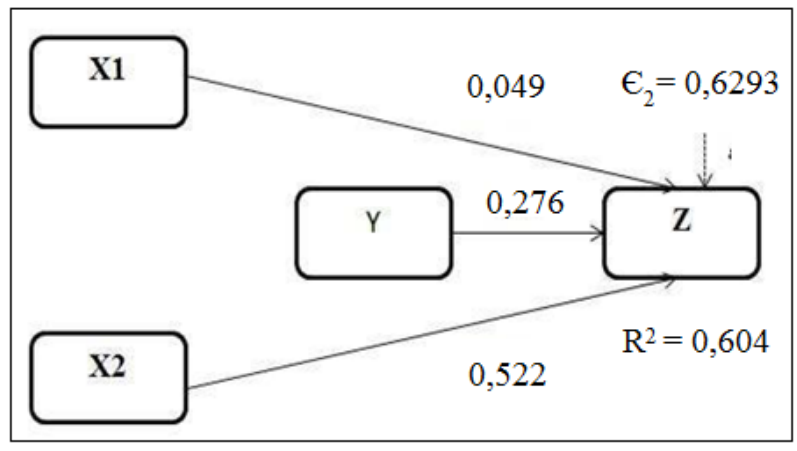

Fig-6: Sub-structure Path Chart Model 2

Thus the structural equation for sub-structure 2 can be obtained as follows:

$$
\begin{aligned}
& Z=\rho z x_{1} X_{1}+\rho z x_{2} X_{2}+\rho z y Y+\epsilon_{2} \\
& Z=0,049 X_{1}+0,522 X_{2}+0,276 Y+0,6293
\end{aligned}
$$

Where is $R^{2}=0,604$

For the value $\epsilon_{1}$ can be searched by the formula:

$$
\epsilon_{1}=\sqrt{ }(1-0,604)=0,6293
$$

Based on the structural equation sub-structure 2, it can be interpreted that:

- $\quad$ Service quality $\left(\mathrm{X}_{1}\right)$ is obtained $\mathrm{Sig}=0,579$ or $>$ $0,05, \mathrm{H}_{0}$ is rejected and $\mathrm{Ha}$ is accepted. Thus it can be concluded that the variable Quality of service $\left(\mathrm{X}_{1}\right)$ does not significantly influence the Customer Loyalty variable $(\mathrm{Z})$ with a beta coefficient of 0,049 . This shows that indirectly, there is no influence between service quality variables $\left(\mathrm{X}_{1}\right)$ on the Customer Loyalty variable (Z).

- Institutional image $\left(\mathrm{X}_{2}\right)$ obtained a value of Sig = 0,000 or, $<0,05$, then $\mathrm{H}_{0}$ is accepted and $\mathrm{Ha}$ is rejected. Thus it can be concluded that the variable institutional image $\left(\mathrm{X}_{2}\right)$ has a significant effect on customer loyalty variable (Z) with a beta coefficient of 0,522 . This shows that there is a positive influence between institutional image variables $\left(\mathrm{X}_{2}\right)$ on Customer Loyalty variables $(\mathrm{Z})$.

- Customer satisfaction (Y) is $\mathrm{Sig}=0,002$ or $<0,05$, $\mathrm{H}_{0}$ is accepted and $\mathrm{Ha}$ is rejected. Thus it can be concluded that the variable customer satisfaction (Y) significantly influences the customer loyalty variable $(\mathrm{Z})$ with a beta coefficient of 0,276 . This shows that there is a positive influence between customer satisfaction variables (Y) on Customer Loyalty (Z) variables.

The following are the results of the analysis of direct and indirect effects based on the model I and II paths as in the table below:

Table-1: Results of Analysis of Direct and Indirect

\begin{tabular}{|l|l|l|l|l|}
\hline No & Variabel & Direct & Indirect & Kriteria \\
\hline 1 & Kualitas Pelayanan & 0,049 & 0,098 & Direct < Indirect \\
\hline 2 & Citra Institusi & 0,522 & 0,120 & Direct > Indirect \\
\hline
\end{tabular}

Source: Processed Research Data (2019)

The results of the table above can be explained as follows:

- On the analysis of the effect of service quality $\left(\mathrm{X}_{1}\right)$ through customer satisfaction $(\mathrm{Y})$ on customer loyalty $(\mathrm{Z})$ it is known that the direct effect of service quality $\left(X_{1}\right)$ on customer loyalty $(Z)$ is 0,049 . While the indirect effect of $\mathrm{X}_{1}$ through $\mathrm{Y}$ on $\mathrm{Z}$ is 0,098 . Then the total effect given $X_{1}$ to $Z$ is the direct effect coupled with indirect effects, which is 0,147 . Based on the results of the calculation above, it is known that the direct effect value is 0,049 and the indirect effect is 0,098 which means that the value of indirect influence is greater than the value of direct influence.

- In the analysis of the influence of institutional image $\left(\mathrm{X}_{2}\right)$ through customer satisfaction $(\mathrm{Y})$ on customer loyalty $(\mathrm{Z})$ it is known that the direct effect of given institutional image $\left(X_{2}\right)$ on customer loyalty $(\mathrm{Z})$ is 0,522 . While the indirect effect of $\mathrm{X}_{2}$ through $\mathrm{Y}$ on $\mathrm{Z}$, is 0,120 . So the total effect given $X_{2}$ to $Z$ is 0,642 . Based on the results of the calculation above it is known that the direct effect value is 0,522 and the indirect effect is 0,120 which means that the value of direct influence is greater than the value of indirect influence. These results indicate that the relationship $\mathrm{X}_{2}$ through $\mathrm{Y}$ has a direct and significant influence on $\mathrm{Z}$.

\section{Determinant Coefficient Analysis $\left(\mathbf{R}^{2}\right)$}

Determination analysis in simple linear regression is used to determine the contribution percentage of the effect of service quality variables $\left(\mathrm{X}_{1}\right)$ and institutional image $\left(\mathrm{X}_{2}\right)$ on customer satisfaction $(\mathrm{Y})$ and customer loyalty $(\mathrm{Z})$. This coefficient shows the percentage of independent variables used in the model able to explain variations in intervening variables and dependent variables.

Based on the calculation results, the results of the determination coefficient of determination of $\mathrm{R}$ Square $\left(R^{2}\right)$ model 1 are 0,536 or $53,6 \%$. This shows that customer satisfaction $(\mathrm{Y})$ is influenced by service quality $\left(\mathrm{X}_{1}\right)$ and institutional image $\left(\mathrm{X}_{2}\right)$ simultaneously and significantly by $53,5 \%$ and the remaining $46,5 \%$ is influenced by other variables outside of this study. As a result of the calculation results obtained the determination coefficient of $\mathrm{R}$ Square $\left(R^{2}\right)$ model 2 is 0,604 or $60,4 \%$. This shows that customer loyalty $(Z)$ is 
influenced by service quality $\left(\mathrm{X}_{1}\right)$, institutional image $\left(\mathrm{X}_{2}\right)$ and customer satisfaction $(\mathrm{Y})$ simultaneously and significantly by $60,4 \%$ and the remaining $39,6 \%$ is influenced by other variables outside of this research.

\section{Interdimensional Correlation Test}

The matrix correlation between dimensions is used to measure the relationship or the relationship of each dimension to the independent variable to the dimensions contained in the intervening variable (customer satisfaction) and the dependent variable (customer loyalty).

Results Analysis of the matrix correlation test between dimensions with the Pearson's Correlation twotailed model can be explained as follows:

- Correlation of service quality variables $\left(X_{1}\right)$ to customer satisfaction (Y). The most powerful dimension of the relationship is the dimension of physical evidence (tangibles) on the dimensions of Performance outcomes, because it has a coefficient of 0,544 (having a "moderate" correlation).

- Correlation of institutional image variables $\left(\mathrm{X}_{2}\right)$ to customer satisfaction (Y). The most powerful dimension of the relationship is the dimension of Corporate identity towards the dimensions of Performance outcomes, because it has a coefficient of 0,656 (having a correlation relationship that is "strong").

- Correlation of service quality $\left(X_{1}\right)$ to customer loyalty $(Z)$. The most powerful dimension of the relationship is the dimension of assurance for the dimensions of Affective loyalty, because it has a coefficient of 0,503 (having a "moderate" correlation).

- Correlation of institutional image variables $\left(\mathrm{X}_{2}\right)$ to customer loyalty $(\mathrm{Z})$. The most powerful dimension of the relationship is the dimension of Personality to the dimensions of Affective loyalty, because it has a coefficient of 0,621 (having a "strong" correlation relationship).

- Correlation of customer satisfaction variable (Y) to customer loyalty $(\mathrm{Z})$. The most powerful dimension of the relationship is the dimensions of Performance outcomes on the dimensions of Affective loyalty, because it has a coefficient of 0,529 (having a "moderate" correlation relationship).

\section{DISCUSSION}

\section{Analysis of the Effect of Service Quality $\left(X_{1}\right)$ on Customer Satisfaction (Y)}

Based on the results of the $\mathrm{T}$ test and the $\mathrm{F}$ test, it shows that service quality has a significant effect on customer satisfaction at Depok Yadika 12 Junior High School. Then it can be concluded that the hypothesis has been proven and acceptable. This is in accordance with the opinion of Lupiyoadi [14], that quality has a very close relationship with customer satisfaction. Quality gives an encouragement to customers to establish a strong relationship with an institution which in this case is school. In the long term this kind of bond allows the school to carefully understand customer expectations and their needs.

Based on the results of the correlation test between dimensions between service quality variables (X1) on customer satisfaction (Y) the strongest dimension of the relationship is the dimension of physical evidence (tangibles) on the dimensions of performance outcomes with a coefficient of 0,544 (having a "moderate" correlation). According to Syahbana [15] states that physical evidence (tangibles) has an influence on the satisfaction of cooperative members. The higher the physical evidence (tangibles) as a dimension of service quality, the higher the satisfaction of cooperative members. Another opinion according to Abdi [16] from the results of the study shows that the dimensions of Tangible and Assurance are dimensions that have a significant effect on satisfaction. The existence of a strong correlation between the dimensions of physical evidence (tangibles) in the form of supporting rooms and facilities, adequate teaching and learning activities equipment, and the appearance of attractive TU staff and teachers, will increase customer satisfaction on the Performance Outcomes dimension.

\section{Analysis of the Effect of Institutional Image $\left(\mathrm{X}_{2}\right)$ on Customer Satisfaction (Y)}

Based on the results of the T test and the F test, it can be stated that partially there is a significant influence between the institutional image of customer satisfaction at Depok Yadika 12 Junior High School. Then it can be concluded that the hypothesis has been proven and acceptable. This is in accordance with Qomariah [17] which states that institutional image variables have a significant effect on student satisfaction.

Based on the results of the correlation test between dimensions between institutional image variables $\left(\mathrm{X}_{2}\right)$ on customer satisfaction $(\mathrm{Y})$ the most powerful dimension of the relationship is the dimension of corporate identity to the dimensions of performance outcomes. Based on this and in accordance with the interpretation of the correlation coefficient according to Sugiyono [18], the dimensions of the institutional image variable that have the dominant relationship to the dimensions of the customer satisfaction variable are the dimensions of the Corporate identity which correlate strongly with the dimensions of Performance outcomes with a coefficient of 0,656 . So that there is a positive influence between institutional image variables and customer satisfaction due to the relationship between the dimensions of corporate identity on institutional image variables with dimensions of performance outcomes on customer satisfaction variables. 
Analysis of the Effect of Service Quality $\left(X_{1}\right)$ on Customer Loyalty (Z)

Based on the results of the T test, it was found that service quality did not have an indirect and insignificant effect on customer loyalty at Depok Yadika 12 Junior High School. So the hypothesis that states service quality has a significant effect on customer loyalty is not proven. Thus, quality services do not guarantee customers will be loyal. According to Aryani and Rosinta [19] as for the causes of the very weak influence of service quality can be analyzed because there are other factors (outside the quality of service factors) that provide a stronger influence on creating loyalty compared to the quality of service factors.

Another opinion according to Mardikawati and Farida [20], that service quality has an indirect influence on customer loyalty through customer satisfaction. Service quality is the expected level of excellence and control of the level of excellence to meet the level of customer satisfaction. If the service received or perceived (perceived service) is as expected, then the quality of service is perceived as good and satisfying so that the quality of service is perceived as very good and quality so that it will affect the level of customer loyalty. Conversely, if the services received are lower than expected, then the quality of service is perceived poorly so that it will have an impact on the decline in the level of customer satisfaction which indirectly causes a decrease in loyalty to the company/agency.

\section{Analysis of the Effect of Institutional Image $\left(\mathrm{X}_{2}\right)$ on Customer Loyalty (Z)}

Based on the results of the $\mathrm{T}$ test and the $\mathrm{F}$ test, it was found that partially there was a significant effect between the institutional image of customer loyalty at Depok Yadika 12 Junior High School. So it was found that the hypothesis was proven and acceptable. The results of this study are supported by previous research conducted by Mutmainnah [21] that institutional image variables have a positive and significant effect on customer loyalty.

Based on the results of the correlation test between dimensions between institutional image (X2) to customer loyalty $(\mathrm{Z})$ the most powerful dimension of the relationship is the dimension of Personality to the dimensions of Affective loyalty. Based on this and in accordance with the interpretation of the correlation coefficient according to Sugiyono [18], the dimensions of the institutional image variable whose dominant relationship to the dimensions of customer loyalty variables are personality dimensions strongly correlated with affective loyalty dimensions with a coefficient of 0,621 . So that the positive influence between institutional image variables and customer loyalty is due to the relationship between personality dimensions on institutional image variables and affective loyalty dimensions on customer loyalty variables.
Analysis of the Effect of Customer Satisfaction (Y) on Customer Loyalty ( $Z$ )

Based on the results of the T test and the F test, it was found that partially there was a significant effect between customer satisfaction on customer loyalty in Depok's Yadika 12 Middle School. So that the hypothesis has been proven and acceptable. This is in accordance with previous research which said that the variable student satisfaction has a significant effect on student loyalty [17].

Based on the results of the correlation test between dimensions between customer satisfaction variables ( $\mathrm{Y}$ ) on customer loyalty $(\mathrm{Z})$. The most powerful dimension of the relationship is the dimensions of Performance outcomes on the dimensions of Affective loyalty, because it has a coefficient of 0.529 (having a "moderate" correlation relationship). It is the law that customer satisfaction greatly influences customer loyalty. This is because customer satisfaction is a very important part of loyalty in continuing school in the same school institution in this case the SMA/SMK Yadika 12.

\section{CONCLUSION \& RECCOMENDATION}

Based on the results of research and discussion on the effect of service quality and institutional image on customer satisfaction and customer loyalty, it can be concluded as follows:

- Service quality has a positive and significant effect on customer satisfaction in Yadika 12 Depok Junior High School. This means that the better the quality of service $\left(\mathrm{X}_{1}\right)$ given, the customer satisfaction (Y) will also be higher. Vice versa, the worse the quality of service $\left(\mathrm{X}_{1}\right)$ given, the customer satisfaction (Y) will also be lower. The positive influence between service quality and customer satisfaction is due to the relationship between the dimensions of tangibles on service quality variables and dimensions of performance outcomes on the variable customer satisfaction.

- Institutional image has a positive and significant effect on customer satisfaction in Yadika 12 Depok Junior High School. This means that the better the image of the institution $\left(\mathrm{X}_{2}\right)$ of a school, the better customer satisfaction ( $\mathrm{Y}$ ) will be. Vice versa, the worse the image of the institution $\left(\mathrm{X}_{2}\right)$ of a school, the customer satisfaction (Y) will also be lower. The existence of a positive influence between institutional image and customer satisfaction is caused by a relationship between the dimensions of corporate identity on the image variable of the institution and the dimensions of performance outcomes on the variable customer satisfaction.

- Service quality does not have an indirect and insignificant effect on customer loyalty at Yadika 12 Depok Junior High School. So the hypothesis that states service quality has a significant effect on customer loyalty is not proven. The causes of the very weak influence of service quality can be 
analyzed because there are other factors (outside the quality of service factors) that provide a stronger influence on creating loyalty compared to the quality of service factors.

- Institutional image has a positive and significant effect on customer loyalty in Yadika 12 Depok Junior High School. This means that the better the image of the institution $\left(\mathrm{X}_{2}\right)$ of a school, the more customer loyalty (Y) will be. Likewise, vice versa, the worse the institutional image $\left(\mathrm{X}_{2}\right)$ of a school, the customer loyalty (Y) will also be lower. The positive influence between institutional image variables and customer loyalty is due to the relationship between personality dimensions on institutional image variables and affective loyalty dimensions on customer loyalty variables.

- Customer satisfaction has a positive and significant effect on customer loyalty in Yadika 12 Depok Junior High School. This means that the more satisfied the customers of a school, the more loyal the customer will be. Vice versa, the more dissatisfied the customers towards a school, the more they will be disloyal or do not want to continue to go to the same school. The positive effect of the variable customer satisfaction with customer loyalty is due to the relationship between the dimensions of performance outcomes on the variable customer satisfaction with the dimensions of affective loyalty on customer loyalty variables.

Referring to the conclusions obtained from this study, here are some applicable and operational suggestions that can be given by the author for Yadika 12 Depok Junior High School, namely:

- Due to the large number of inadequate facilities in most classes in Yadika 12 Depok Junior High School during data collection, such as air conditioners that do not turn on so that the class becomes hot and uncomfortable. Therefore, researchers suggest that they can improve and develop the quality of their services sustainably in this case the tangible dimension of dimensions by focusing on the comfort of the classroom atmosphere, adequate teaching and learning activities, and including skilled employees. The appearance and capabilities of physical facilities and infrastructure must be reliable, because the surrounding environment is evidence of the services provided. So that it is expected to be achieved and the fulfillment of customer expectations that will lead to customer satisfaction.

- In maintaining the institutional image of a school in this case the dimensions of corporate identity, Yadika 12 Depok Junior High School must be able to maintain performance outcomes by providing and improving services in accordance with expectations, namely listening to complaints and input from students or parents properly and directly processing or handling the problem, always check existing school facilities whether they are still functioning properly and whether they are still adequate or not. That way Yadika 12 Junior High School will be more easily known and will become a superior and well-known school.

- The ability of Yadika 12 Depok Junior High School staff and teachers in terms of understanding, politeness, and cleverness in providing clear and easy-to-understand information to parents and students can show the quality of service that is free from risk or a customer's doubts, which in turn will form a certainty in self customer. This will lead to an attitude of loyalty, especially in the affevtive loyalty dimension. This loyalty is based on customer feelings and commitment to a brand. If the customer has a positive attitude towards the brand, then the customer will develop affective loyalty.

- Trust and pride of students and parents towards Yadika 12 Depok Junior High School will create a sense of loyalty. High appreciation for a school institution if it is able to establish customer loyalty and can refer the company to its peer partners. This means that trust and satisfaction are inherent in his heart. This needs to be maintained and sought new or innovative things so that this loyalty continues to be formed. Therefore, Yadika 12 Junior High School must be able to maintain the image of the institution that has been built so that it will be easier for schools to get new students each year and can retain existing students.

- With performance outcomes of Yadika 12 Depok Junior High School that are in line with the expectations of students and parents. Then it is expected that Yadika 12 Junior High School can maintain, improve and be able to innovate even more. For example by paying attention and checking existing facilities whether they are still functioning properly or not, employ responsive staff and teachers, paying attention to neatness and cleanliness are important in increasing customer satisfaction. Customer satisfaction must be a priority and must be achieved by staff and teachers. Thus customer loyalty to Yadika 12 Junior High School will increase.

\section{REFERENCE}

1. Jasfar, F. (2005). Manajemen Jasa Pendekatan Terpadu. Bogor: Ghalia Indonesia.

2. Matzler, K., Sauerwein, E., \& Heischmidt, K. (2003). Importance-performance analysis revisited: the role of the factor structure of customer satisfaction. The Service Industries Journal, 23(2), 112-129.

3. Saktiani, G. A. (2015). Pengaruh Kualitas Layanan dan Citra Perusahaan terhadap Kepuasan Pelanggan dan Word of Mouth. JISIP: Jurnal Ilmu Sosial Dan Ilmu Politik, 4(2), 342-353.

4. Misner, I. R. (1999). The World's Best Known Marketing Secret: Building Your Business with Word of Mouth Marketing. Virginia: Paperback. 
5. Martenson, R. (2007). Corporate Brand Image, Satisfaction and Store Loyalty: A Study of the Store as Brand and Manufacturer Brand. International Journal of Retail and Distribution Management, 35(7), 544-555.

6. Parasuraman, S., Thing, G. S., \& Dhanaraj, S. A. (2014). Polyherbal formulation: Concept of ayurveda. Pharmacognosy reviews, 8(16), 73.

7. Pratama, H. F. (2016). Pengaruh Kualitas Pelayanan Petugas terhadap Kepuasan Pengunjung di Objek Wisata Sejarah Benteng Marlborough di Kota Bengkulu. Ekombis Review, 4(1), 24-35.

8. Kottler, P., \& Keller, K. L. (2012). Marketing Management. Edisi 14. Jakarta: PT. Indeks Kelompok Gramedia.

9. Jasfar, F., dan Robert, K. (2012). Sinergi Kualitas Jasa Ritel dan Pemasaran Kerelasian terhadap Ritensi Pelanggan. Jakarta: Penerbit Universitas Trisakti.

10. Hoq, M. Z., Sultana, N., \& Amin, M. (2010). The effect of trust, customer satisfaction and image on customers' loyalty in islamic banking sector. South asian journal of management, 17(1), 70-93.

11. Kotler, P., Armstrong, G. (2008). Prinsip-Prinsip Pemasaran. Edisi 12. Jilid 1. Jakarta: Erlangga.

12. Tjiptono, F. (1997). Strategy Pemasaran. Edisi 1. Yogyakarta: Penerbit Andi.

13. Tjiptono, F., \& Chandra, G. (2012). Pemasaran Strategik. Yogyakarta: Penerbit Andi.

14. Lupiyoadi, R., \& dan Hamdani. (2008). Bauran Pemasaran Bisnis Jasa. Jakarta: Salemba Empat.

15. Syahbana, Donny. (2016). "Pengaruh Lima Dimensi Kualitas Pelayanan Terhadap Kepuasan
Anggota Koperasi Susu Warga Mulya Purwobinangun Pakem Selman”. Skripsi. Jurusan Pendidikan Ekonomi, Fakultas Ekonomi. Universitas Negeri Yogyakarta. Yogyakarta.

16. Abdi, S. (2018). Pengaruh Dimensi Kualitas Pelayanan Terhadap Kepuasan Pelanggan Lembaga Bimbingan Belajar Ganesha Operation Cabang Serang Banten. Tesis. Program Studi Magister Manajemen, Program Pascasarjana. Universitas Mercu Buana. Jakarta.

17. Qomariah, N. (2012). Pengaruh Kualitas Layanan dan Citra Institusi terhadap Kepuasan dan Loyalitas Pelanggan (Studi pada Universitas Muhammadiyah di Jawa Timur). Jurnal Aplikasi Manajemen, 10(1), 177-187.

18. Sugiyono. (2006). Metode Penelitian Bisnis. Bandung: CV Alfabeta.

19. Aryani, D., \& Rosinta, F. (2010). Pengaruh Kualitas layanan terhadap kepuasan pelanggan dalam membentuk loyalitas pelanggan. Bisnis \& Birokrasi, Jurnal Ilmu Administrasi dan Organisasi, 17(2), 114-116.

20. Mardikawati, W., \& dan Farida, N. (2013). Pengaruh Nilai Pelanggan dan Kualitas Layanan terhadap Loyalitas Pelanggan, Melalui Kepuasan Pelanggan Pada Pelanggan Bus Efisiensi (Studi PO Efisiensi Jurusan Yogyakarta-Cilacap). Jurnal Administrasi Bisnis, 2(1), 64-75.

21. Mutmainnah. (2017). Pengaruh Kualitias Layanan dan Citra Perusahaan Terhadap Kepuasan dan Loyalitas Nasabah. Jurnal Manajemen dan Pemasaran Jasa, 10(2), 201-216. 